\title{
ARHGAP29 wt Allele
}

National Cancer Institute

\section{Source}

National Cancer Institute. ARHGAP29 wt Allele. NCI Thesaurus. Code C101360.

Human ARHGAP29 wild-type allele is located in the vicinity of 1p22.1 and is approximately $126 \mathrm{~kb}$ in length. This allele, which encodes Rho GT Pase-activating protein 29, plays a role in the modulation of signaling. 